26. Bateman ED, Clark TJ, Frith L, et al. Rate of response of individual asthma control measures varies and may overestimate asthma control: an analysis of the goal study. J Asthma 2007;44:667-73.

27. Bereznicki BJ, Peterson GM, Jackson SL, et al. Pharmacist-initiated general practitioner referral of patients with suboptimal asthma management. Pharm World Sci 2008;30:869-75.

28. Price D, Thomas M. Breaking new ground: challenging existing asthma guidelines. BMC Pulm Med 2006:6(Suppl 1):S6.

29. Schneider A, Biessecker K, Quinzler R, et al. Asthma patients with low perceived burden of illness: a challenge for guideline adherence. J Eval Clin Pract 2007;13:846-52.
30. Powell CV, Kelly AM, Kerr D. Lack of agreement in classification of the severity of acute asthma between emergency physician assessment and classification using the National Asthma Council Australia guidelines (1998). Emerg Med (Fremantle) 2003:15:49-53.

31. Adams RJ, Weiss ST, Fuhlbrigge A. How and by whom care is delivered influences anti-inflammatory use in asthma: results of a national population survey. J Allergy Clin Immunol 2003:112:445-50.

32. Bereznicki BJ, Peterson GM, Jackson SL, et al. Data-mining of medication records to improve asthma management. Med J Aust 2008;189:21-5.

\section{Orthopnoea and arm weakness}

\section{PULMONARY PUZZLE}

A 70-year-old Caucasian man was transferred back to New Zealand from an Italian hospital having been admitted there 6 weeks earlier with acute dyspnoea. There was no associated cough or fever and, despite antibiotic treatment, he remained dyspnoeic at rest with persistent orthopnoea. His left shoulder had been weak for over 10 years but he had recently noticed weakness in the right shoulder and arm. He had moderate chronic obstructive lung disease secondary to smoking. On examination he had a short neck, with limited range of movement in all directions, and a body mass index of 32 . His respiratory rate was $24 / \mathrm{min}$, oxygen saturation $80 \%$ on air. The chest was mildly hyperinflated but expansion was decreased and lung bases were dull to percussion with decreased breath sounds. There were no signs of pulmonary hypertension. Bilaterally, there was severe weakness in the shoulders (power grade $2 / 5$ on the right, $1 / 5$ on the left) and very mild weakness of arm flexion (power grade 5-/5). Tone was increased and reflexes brisk in all limbs. He was in asymptomatic urinary retention. An arterial blood gas on air was consistent with chronic type II respiratory failure ( $\mathrm{pH} 7.41, \mathrm{PCO}_{2} 66 \mathrm{~mm} \mathrm{Hg}$, $\mathrm{PO}_{2} 42 \mathrm{~mm} \mathrm{Hg}, \mathrm{HCO}_{3}{ }^{-} 41 \mathrm{mmol} / \mathrm{l}$ ); spirometric tests showed a $52 \%$ reduction in his vital capacity in the lying position compared with sitting (0.71 1 to $1.46 \mathrm{l}$ ) and the chest radiograph showed bilateral loss of lung volume with elevated hemidiaphragms. A sniff test showed bilateral diaphragmatic paralysis without paradoxical movement and serum creatine kinase levels were normal. A CT scan showed moderate bibasal atelectasis only. MRI of the neck demonstrated extensive vertebral abnormalities in the cervical spine (fig 1).

\section{QUESTION}

What is the diagnosis and what further investigations are required?

See page 1069 for answers

\section{H K Chen, ${ }^{1}$ D Jardine, ${ }^{2}$ L Beckert ${ }^{1}$}

${ }^{1}$ Department of Respiratory Medicine, Christchurch Hospital, Christchurch, New Zealand;

${ }^{2}$ Department of General Medicine, Christchurch Hospital, Christchurch, New Zealand

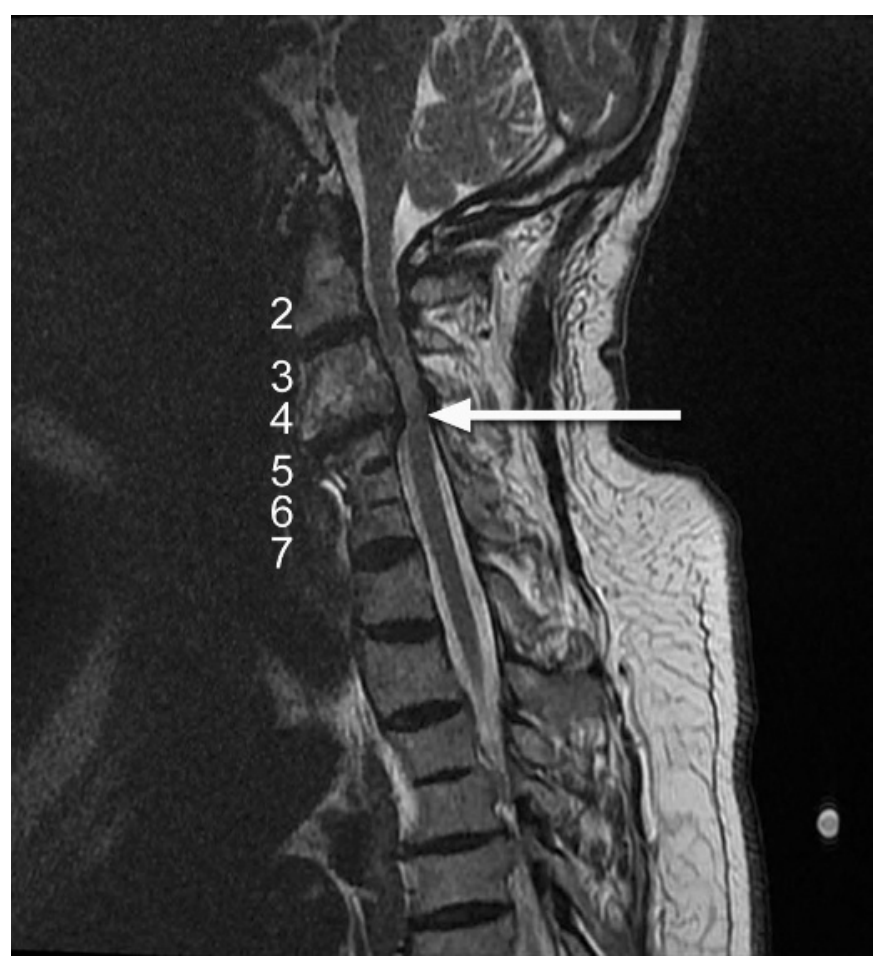

Figure $1 \mathrm{~T} 2 \mathrm{MRI}$ of sagittal cervical spine showing congenital synostosis of the $\mathrm{C} 3 / \mathrm{C} 4$ and $\mathrm{C} 5 / \mathrm{C} 6 / \mathrm{C} 7$ vertebrae consistent with KlippelFeil syndrome. The C3/4 disc-osteophyte complex is causing severe compression to the cord (arrow) and myelomalacia above this level. The relevant vertebral bodies are numbered.

Correspondence to: D L JardineGeneral Medicine, Christchurch Hospital, Christchurch 8011, New Zealand; david.jardine@cdhb.govt.nz

Acknowledgements: We thank Tony Goh for his interpretation of the MRI studies and Grant Carroll for undertaking and interpreting the nerve conduction studies. The figure was prepared by The Medical Illustrations Department, Christchurch Hospital.

Competing interests: None.

Patient consent: Obtained.

Thorax 2009;64:1031. doi:10.1136/thx.2009.121632 
7. Kaplan V, Clermont G, Griffin MF, et al. Pneumonia. Still the old man's friend? Arch Intern Med 2003;163:317-23.

8. BOS. Qualitätsreport 2005; http://www.bqs-qualitaetsreport.de/Webs/bqs/qualrep/ 2005/ (accessed 25 Jul 2009).

9. BOS. Qualitätsreport 2006; http://www.bqs-qualitaetsreport.de/Webs/bqs/qualrep/ 2006/ (accessed 25 Jul 2009).

10. Lim WS, van der Eerden MM, Laing R, et al. Defining community acquired pneumonia severity on presentation to hospital: an international derivation and validation study. Thorax 2003;58:377-382

11. http://www.destatis.de/jetspeed/portal/cms/Sites/destatis/Internet/DE/Navigation/ Statistiken/Bevoelkerung/Bevoelkerung.psml (accessed 25 Jul 2009).

12. Almirall J, Bolíbar I, Vidal J, et al. Epidemiology of community-acquired pneumonia in adults: a population-based study. Eur Respir J 2000:15:757-63.

13. Jokinen C, Heiskanen $\mathrm{L}$, Juvonen $\mathrm{H}$, et al. Incidence of community-acquired pneumonia in the population of four municipalities in eastern Finland. Am J Epidemiol 1993:137:977-88.

14. Gutiérrez F, Masiá M, Mirete $\mathrm{C}$, et al. The influence of age and gender on the population-based incidence of community-acquired pneumonia caused by different microbial pathogens. J Infect 2006;53:166-74

15. Marston BJ, Plouffe JF, File TM Jr, et al. Incidence of community-acquired pneumonia requiring hospitalization. Results of a population-based active surveillance Study in Ohio. The Community-Based Pneumonia Incidence Study Group. Arch Intern Med 1997:157:1709-18.

16. Fry AM, Shay DK, Holman RC, et al. Trends in hospitalizations for pneumonia among persons aged 65 years or older in the United States, 1988-2002. JAMA 2005:294:2712-9.

17. Jackson ML, Neuzil KM, Thompson WW, et al. The burden of community-acquired pneumonia in seniors: results of a population-based study. Clin Infect Dis 2004;39:1642-50.

18. Ewig S, de Roux A, Bauer T, et al. Validation of predictive rules and indices of severity for community acquired pneumonia. Thorax 2004:59:421-7.

19. Aujesky D, Auble TE, Yealy DM, et al. Prospective comparison of three validated prediction rules for prognosis in community-acquired pneumonia. Am J Med 2005; 118:384-92.
20. Kollef MH, Shorr A, Tabak YP, et al. Epidemiology and outcomes of health-careassociated pneumonia: results from a large US database of culture-positive pneumonia. Chest 2005;128:3854-62

21. Micek ST, Kollef KE, Reichley RM, et al. Health care-associated pneumonia and community-acquired pneumonia: a single-center experience. Antimicrob Agents Chemother 2007; 51:3568-73.

22. Houck PM, Bratzler DW, Nsa W, et al. Timing of antibiotic administration and outcomes for Medicare patients hospitalized with community-acquired pneumonia. Arch Intern Med 2004;164:637-44.

23. Barlow G, Nathwani D, Williams F, et al. Reducing door-to-antibiotic time in community-acquired pneumonia: controlled before-and-after evaluation and costeffectiveness analysis. Thorax 2007:62:67-74/

24. Rosón B, Carratalà J, Dorca J, et al. Etiology, reasons for hospitalization, risk classes, and outcomes of community-acquired pneumonia in patients hospitalized on the basis of conventional admission criteria. Clin Infect Dis 2001:33:158-65.

25. Menéndez R, Cremades MJ, Martínez-Moragón E, et al. Duration of length of stay in pneumonia: influence of clinical factors and hospital type. Eur Respir J 2003;22:643-8.

26. Bauer TT, Ewig S, Marre R, Suttorp N, Welte T, The CAPNETZ Study Group. CRB-65 predicts death from community-acquired pneumonia. J Intern Med 2006;260:93-101.

27. Capelastegui A, España PP, Quintana JM, et al. Validation of a predictive rule for the management of community-acquired pneumonia. Eur Respir J 2006:27:151-7.

28. Niederman MS, Feldman C, Richards GA. Combining information from prognostic scoring tools for CAP: an American view on how to get the best of all worlds. Eur Respir J 2006;27:9-11.

29. Ewig S, Torres A, Woodhead M. Assessment of pneumonia severity: a European perspective. Eur Respir J 2006:27:6-8.

30. Marrie TJ, Fine MJ, Kapoor WN, et al. Community-acquired pneumonia and do not resuscitate orders. J Am Geriatr Soc 2002;50:290-9.

31. Van der Steen JT, Ooms ME, Adèr HJ, et al. Withholding antibiotic treatment in pneumonia patients with dementia: a quantitative observational study. Arch Intern Med 2002:162:1753-60.

32. Carratalà J, Mykietiuk A, Fernández-Sabé N, et al. Health care-associated pneumonia requiring hospital admission: epidemiology, antibiotic therapy, and clinical outcomes. Arch Intern Med 2007:167:1393-9.

33. Kothe H, Bauer T, Marre R, et al. Outcome of CAP: influence of age, residence status, and antimicrobial treatment. Eur Respir J 2008;32:139-46.

\section{Pulmonary puzzle}

\section{ANSWER}

From the question on page 1031

The scan showed synostoses of the $\mathrm{C} 3 / \mathrm{C} 4$ and $\mathrm{C} 5 / \mathrm{C} 6 / \mathrm{C} 7$ vertebrae, consistent with Klippel-Feil syndrome. At C3/C4 the disc-osteophyte complex was compressing the adjacent cord, causing severe myelomalacia well above this level. Phrenic nerve studies, including amplitudes and conduction velocities, were normal bilaterally, reliably excluding lower motor neurone pathology. ${ }^{1}$ Bilateral diaphragmatic paralysis, demonstrated by fluoroscopic monitoring during the sniff test, was therefore secondary to interruption of the descending corticospinal pathways supplying the phrenic nerve cell bodies, most of which lie in the $\mathrm{C} 4$ neuromere adjacent to the $\mathrm{C} 2 / \mathrm{C} 3$ disc. This would account for his respiratory failure and we suspect that the interruption was included in the extensive area of myelomalacia above the cord lesion. This may initially have been unilateral and asymptomatic, progressing only to respiratory failure when the right side became involved. ${ }^{2}$ His ability to compensate for this would have been decreased by his underlying chronic obstructive airways disease and high body mass index.

Klippel-Feil syndrome is a congenital condition (incidence 1:40 000 births) of uncertain inheritance characterised by synostosis of the cervical spine at one or multiple levels, involving the vertebral bodies, facet joints and posterior arches. The neck may be short and webbed with restricted movement and the hairline low. Associated conditions include other musculoskeletal deformities, deafness, heart defects and genitourinary abnormalities. ${ }^{3}$ Neurological complications secondary to spinal cord and nerve root compression may occur in childhood or later. The differential diagnosis of bilateral diaphragmatic paralysis includes motor neurone disease, multiple sclerosis, cervical myelopathy secondary to degenerative spondylosis and spinal tumours. ${ }^{45}$ The rapid onset of his dyspnoea and absence of lower motor neurone pathology is against motor neurone disease. His dyspnoea has subsequently improved with conservative treatment.

\section{REFERENCES}

1. Loh L, Goldman M, Newsom Davis J. Assessment of diaphragm function. Medicine 1977;56:165-9.

2. Hayashi H, Kihara $S$, Hoshimaru M, et al. Diaphragmatic paralysis caused by cervical spondylosis. J Neurosurg: Spine 2005:2:604-7.

3. Tracy MR, Dormans JP, Kusumi K. Klippel-Feil syndrome: clinical features and current understanding of aetiology. Clin Orthop Rel Res 2004;424:183-90.

4. Suga K, Motoyama K, Kume N, et al. Respiratory failure and pulmonary hypertension associated with Klippel-Feil syndrome. Ann Nucl Med 1999;13:441-6.

5. Chan CK, Loke J, Virgulto JA, et al. Bilateral diaphragmatic paralysis: clinical spectrum, prognosis, diagnostic approach. Arch Phys Med Rehabil 1988;69:976-9 